University of Nebraska - Lincoln

DigitalCommons@University of Nebraska - Lincoln

1988

\title{
Electrophoretic Monomorphism in Six Biotypes and Two Populations of the Hessian Fly (Diptera: Cecidomyiidae)
}

\author{
Stanley G. Wells \\ Formerly USDA-ARS, Dep. of Entomology, Michigan State Univ., E. Lansing, MI 48823 \\ Daniel J. Howard \\ Biology Dep., Museum of N. Arizona, Rt. 4, Box 720, Flagstaff, AZ 86001 \\ Julie L. Adams \\ Dep. of Biomedical Sci., Western Michigan Univ., Kalamazoo, MI 49008 \\ Jonathan Arnold \\ Dep. of Molecular and Population Genetics, Univ. of Georgia, Athens, GA 30602
}

Follow this and additional works at: https://digitalcommons.unl.edu/entomologyother

Part of the Entomology Commons

Wells, Stanley G.; Howard, Daniel J.; Adams, Julie L.; and Arnold, Jonathan, "Electrophoretic Monomorphism in Six Biotypes and Two Populations of the Hessian Fly (Diptera: Cecidomyiidae)" (1988). Entomology Papers from Other Sources. 79.

https://digitalcommons.unl.edu/entomologyother/79

This Article is brought to you for free and open access by the Entomology Collections, Miscellaneous at DigitalCommons@University of Nebraska - Lincoln. It has been accepted for inclusion in Entomology Papers from Other Sources by an authorized administrator of DigitalCommons@University of Nebraska - Lincoln. 


\title{
Electrophoretic Monomorphism in Six Biotypes and Two Populations of the Hessian Fly (Diptera: Cecidomyiidae)
}

\author{
STANLEY G. WELLSO, ${ }^{1}$ DANIEL J. HOWARD, ${ }^{2}$ \\ JULIE L. ADAMS, ${ }^{3}$ AND JONATHAN ARNOLD ${ }^{4}$ \\ U.S. Department of Agriculture, Agricultural Research Service, \\ Department of Entomology, Purdue University, \\ West Lafayette, Indiana 47907
}

\begin{abstract}
Ann. Entomol. Soc. Am. 81(1): 50-53 (1988)
ABSTRACT Six biotype bulk populations and two geographic populations of the Hessian fly, Mayetiola destructor (Say), were analyzed at 15 presumptive genetic loci using starch gel electrophoresis. Fourteen of the 15 loci appeared monomorphic. One locus, Pgi, varied in biotypes B, E, and a population from Mason, Mich. The level of genetic variation among Hessian fly populations is among the lowest reported for insects. Genetic differentiation among Hessian fly biotypes and populations is also low, ranging from a Nei's D of 0.000 to 0.002 . Protein electrophoresis does not appear to provide a quick procedure to identify Hessian fly biotypes.
\end{abstract}

KEY WORDS Insecta, Mayetiola destructor, electrophoresis, monomorphism

HatchetT \& Gallun (1970) characterized the Hessian fly, Mayetiola destructor (Say), and wheat as having a gene-for-gene relationship, each resistant gene of the latter having a complementary gene for survival in the former. Currently, 13 of the 16 biotypes characterized by Gallun (1977) from the United States have been isolated and identified, based on the virulence of larvae from individual progenies on wheats possessing different genes for resistance. Identifying the Hessian fly biotypes requires about 3-4 mo and is quite labor intensive (Hatchett \& Gallun 1968). Generally, the procedure calls for collecting the insects in the field, increasing their number in the laboratory, and then exposing the progeny of single female flies to wheats with different genes for resistance. Following the procedure of Sosa \& Gallun (1973), Hessian fly biotypes can be purified and assigned a biotype designation.

New fly biotypes may arise from one or a few founder individuals that harbor a mutant gene conferring virulence to a particular strain of wheat. Because a founder event can greatly affect the frequency of a particular allele (Lewontin 1965) and because gene exchange among different biotypes may be quite limited (although this is unknown), it is possible that genetic differentiation exists among Hessian fly biotypes at loci other than those responsible for overcoming host-plant resistance. To

\footnotetext{
' Formerly USDA-ARS, Dep. of Entomology, Michigan State Univ., E. Lansing, MI 48823.

${ }^{2}$ Biology Dep., Museum of N. Arizona, Rt. 4, Box 720, Flagstaff, AZ 86001

${ }^{3}$ Dep. of Biomedical Sci., Western Michigan Univ., Kalamazoo, MI 49008.

${ }^{4}$ Dep of Molecular and Population Genetics, Univ. of Georgia, Athens, GA 30602.
}

evaluate this possibility, and whether electrophoretic methods would be useful in identifying Hessian fly biotypes, horizontal starch gel electrophoresis was used to examine the genetic variation of the Hessian fly.

\section{Materials and Methods}

Six biotype bulk populations (B, C, D, E, GP, and $\mathrm{L}$ ) and two geographic populations (Mason, Mich., and Prosser, Wash.) were reared on wheat until more than 100 late third instars and 100 puparia of each biotype and population were available for storage at $-89^{\circ} \mathrm{C}$. Horizontal starch gel electrophoretic techniques adapted from Selander et al. (1971) were used to evaluate variation at genes coding for soluble enzymes. An individual larva or puparium was macerated in a drop of deionized water, and the homogenate was used to soak filter paper wicks. Between 100-120 larvae or puparia were studied for each biotype or population, except biotype B where 170 individuals of the two life stages were studied. By staining for 11 enzymes, 15 loci could be scored (Table 1). Four larvae and puparia of biotype B were run as internal standards on all gels.

\section{Results and Discussion}

Fourteen of the 15 scorable loci appeared entirely monomorphic. One locus, Pgi, exhibited variation in biotypes $\mathrm{B}$ and $\mathrm{E}$ and in the Mason, Mich., population (Table 2). Late instars exhibited a single region of multiple smeary $P g i$ bands, which we demonstrated was due to plant material in the gut rather than to the $P g i$ locus of the insect. $\mathrm{Pu}$ paria, which usually harbor little plant material, 
Table 1. Enzymes, electrophoretic buffers, and Hessian fly developmental stages studied

\begin{tabular}{|c|c|c|c|}
\hline Enzyme & Loci & $\begin{array}{c}\text { Buff- } \\
\text { er }^{a}\end{array}$ & $\begin{array}{l}\text { Insect } \\
\text { stage }^{b}\end{array}$ \\
\hline \multirow[t]{3}{*}{ Aconitase } & Acon-1 & II & L \\
\hline & Acon-2 & II & $\mathbf{L}, \mathbf{P}$ \\
\hline & Acon-3 & II & $\mathrm{L}, \mathrm{P}$ \\
\hline Alcohol dehydrogenase & $A d h$ & III & $\mathbf{L}$ \\
\hline Adenylate kinase & $A k$ & II & L, P \\
\hline \multirow[t]{2}{*}{ Hexokinase } & $H k-1$ & II & $\mathbf{L}, \mathbf{P}$ \\
\hline & $H k-2$ & II & $\mathbf{L}, \mathbf{P}$ \\
\hline Isocitrate dehydrogenase & $I d h$ & II & $\mathrm{L}, \mathbf{P}$ \\
\hline Malic enzyme & $\mathrm{Me}$ & II & $\mathbf{L}, \mathbf{P}$ \\
\hline Mannose phosphate isomerase & $M p i$ & II & $\mathrm{L}, \mathrm{P}$ \\
\hline \multirow[t]{2}{*}{ Phosphogluconate dehydrogenase } & Pgd-1 & II & $\mathrm{L}$ \\
\hline & Pgd-2 & II & $\mathbf{L}, \mathrm{P}$ \\
\hline Phosphoglucose isomerase & $P g i$ & I & $\mathbf{P}$ \\
\hline Phosphoglucomutase & $P_{g m}$ & II & $\mathbf{L}, \mathbf{P}$ \\
\hline Triose phosphate isomerase & $T p i$ & II & $\mathrm{L}, \mathrm{P}$ \\
\hline
\end{tabular}

a (I) Electrode buffer: $0.3 \mathrm{M}$ boric acid and $0.06 \mathrm{M}$ sodium hydroxide, $\mathrm{pH} 8.2$; gel buffer: $0.076 \mathrm{M}$ Tris and $0.005 \mathrm{M}$ monohydrate citric acid, pH 8.7, run at $50 \mathrm{~mA}$ for $1 \mathrm{~h}$, then $65 \mathrm{~mA}$ for 2 additional h (Selander et al. 1971). (II) Electrode buffer: 0.1 $M$ Tris, $0.1 M$ malic acid, $0.01 M$ EDTA, $0.01 M$ MgCl-6HO, $\mathrm{pH}$ 7.6; gel buffer: $1: 10$ dilution of the electrode buffer, $\mathrm{pH} 7.6$, run at $50 \mathrm{~mA}$ for $1 \mathrm{~h}$, then $100 \mathrm{~mA} / 100 \mathrm{~V}$ for 5 additional h (Brewer 1970). (III) Electrode buffer: $0.3 M$ Tris, pH 8.6; gel buffer: 0.02 $M$ Tris, $\mathrm{pH} 8.6$, run at $50 \mathrm{~mA}$ for $1 \mathrm{~h}$, then $65 \mathrm{~mA}$ for 4 additional h (Harris \& Hopkinson 1976).

${ }^{b} \mathrm{~L}$, late instar larva; $\mathrm{P}$, puparium (prepupal-pupal stage).

displayed Pgi banding patterns more typical of a dimeric enzyme. Presumed homozygotes were single-banded, and presumed heterozygotes were three-banded. Eleven of 813 puparia characterized displayed multiple smeary bands; these aberrant bands were ascribed to the presence of plant material in the gut and were not scored.

Because of the presence of rare alleles, an exact test of the Hardy-Weinberg law was used (Emigh 1980). Briefly, this test is based on the exact probability $(P)$ of obtaining the genotypic array $N=$ (NAA, NAB, NBB) given the allelic array $n=(\mathrm{nA}$, $\mathrm{nB})$ by generating all samples $N$ with allelic composition $n$. For each of these samples we calculate the conditional probability $P$ and summed those with $P$ 's less than the one $P$ observed. This sum of probabilities for samples more unusual than the one observed is the significance $(\alpha)$ of the exact test. In the Mason sample the genotype frequencies displayed a highly significant deviation from HardyWeinberg equilibrium ( $\alpha=0.0000055)$, and in biotype $\mathrm{E}$ the deviation approaches significance $(\alpha=$ 0.0679 ) with a deficiency of heterozygotes in both samples. The biotype $B$ population appears to be in Hardy-Weinberg equilibrium $(\alpha=0.2728)$.

The inbreeding coefficient $\mathrm{F}$ can be used to summarize the heterozygote deficiency in the Mason sample and in biotype $\mathrm{E}$ :

$$
\mathrm{F}=\frac{\mathrm{H}_{\mathrm{E}}-\mathrm{H}_{\mathrm{o}}}{\mathrm{H}_{\mathrm{E}}}
$$

The expected $\mathrm{H}$ is simply the Hardy-Weinberg proportion of heterozygotes. Pooling heterozygote classes gives $F=0.283$ for the Mason sample, and a highly significant $\chi^{2}$ value of $10.849(\mathrm{df}=1$; $P<0.005$ ) (Spiess 1977). Pooling is not required for biotype $\mathrm{E}$ because there is only one heterozygote class and $\mathrm{F}=0.302$, producing a $\chi^{2}$ value of $9.85(\mathrm{df}=1 ; P<0.005)$. A comparison of genotype frequencies observed, expected under random mating, and assuming the inbreeding coefficients calculated above, demonstrates that most of the observed genotype frequencies in biotype $\mathbf{E}$ and the Mason sample fit better under an inbred model than a random-mating model. The sole exception was the 100/135 class in the Mason sample.

Average observed heterozygosities for the populations range from 0.000 to 0.015 , the mean number of alleles per locus range from 1.00 to 1.13 , and percent loci polymorphic (using the $0.99 \mathrm{cri}$ terion) for the three samples exhibiting Pgi variation were each 1.07. According to all three measures, the genetic variation in Hessian fly populations is remarkably low. Mean $\mathbf{H}$ among insects, excluding Drosophila melanogaster (Meigen), is 0.0743 (Nevo 1978). Genetic identities (Nei 1972) among all pairs of populations or biotypes range from 1.000 to 0.998 .

Lack of genetic differentiation of the Hessian fly at $\mathbf{1 5}$ loci coding for soluble enzymes indicates that protein electrophoresis will not circumvent the tedious process of identifying Hessian fly biotypes via rearing studies. Extraordinarily low levels of protein variability in Hessian fly populations may be attributable to an initial founder event when this fly was introduced from Europe and then to subsequent population bottlenecks as the fly was forced to adapt to new resistant varieties of wheat. Theoretical studies indicate that a significant loss of genetic variation can occur after a founder event if the bottleneck persists for many generations ( $\mathrm{Ma}$ ruyama \& Fuerst 1985). Empirical studies also implicate founding events and population bottlenecks in the loss of protein variability (Harrison et al. 1983). It is difficult to invoke these explanations here, because the history of the Hessian fly's invasion is not well documented, and we have not examined protein variability in possible source populations.

Despite the low protein variability in Hessian fly populations, this pest has managed time and time again to overcome new resistance genes in wheat. This may mean that loci responsible for overcoming host plant resistance harbor greater variation than loci coding for soluble proteins. To determine whether the Hessian fly gene pool is, in general, depauperate in variation will require morphological, developmental, and DNA-sequence studies.

The heterozygote deficiency at the Pgi locus observed in the Mason population and biotype $\mathrm{E}$ ( $\mathrm{Ta}$ ble 2) can be caused by a number of factors, including population subdivision into small breeding units, assortative mating for homozygotes, and selection against heterozygotes. Another possible explanation is that patterns of variation at $P g i$ are not under single-locus control, as assumed here. 
Table 2. Genotype frequencies of the Pgi locus in six biotype bulk populations and two populations of the Hessian fly

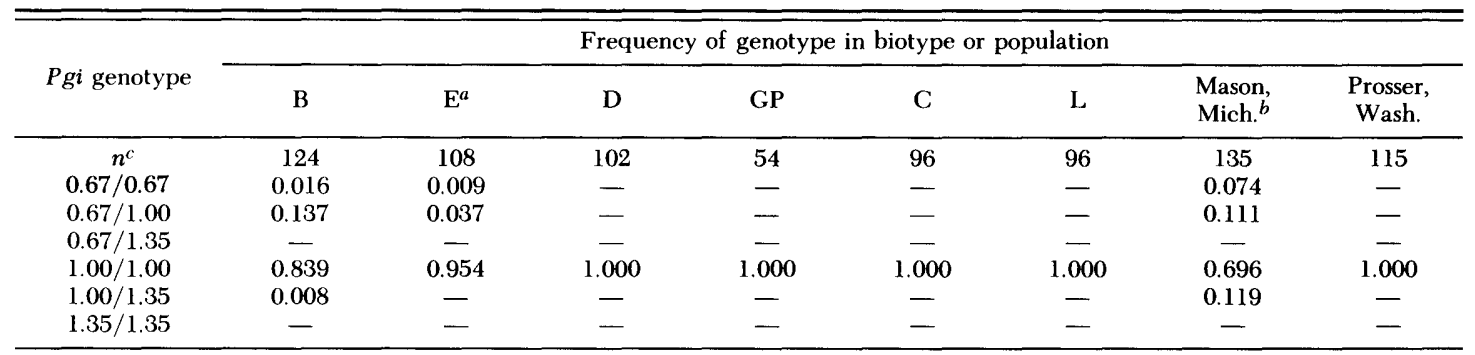

${ }^{a}$ Genotype frequencies in population deviate significantly from Hardy-Weinberg expectations at the 0.10 level

${ }^{b}$ Genotype frequencies in population deviate significantly from Hardy-Weinberg expectations at the 0.005 level or less.

$c_{n}$, number of individuals studied.

Until the proper breeding studies are conducted, the possibility cannot be eliminated that patterns of variation are influenced by multiple loci or environmental factors. If variation of the Pgi enzyme is influenced by other than its DNA coding sequence, there is no reason to expect variation patterns to conform with single-locus population genetic models. If the variation is under single-locus control, probable explanations for the heterozygote deficiency are assortative mating for homozygotes or selection acting directly on the Pgi locus or on linked loci. Population subdivision into small breeding units is an unlikely explanation because the heterozygote deficiency persists in at least some laboratory populations (e.g., biotype E). Of course, a real understanding of the cause of the heterozygote deficiency must include knowledge of the fly's dispersal patterns and behavior, and of selective value differences among genotypes.

As a final note, it is intriguing that the highest level of heterozygosity was found in the only population not exposed to laboratory rearing. This may mean that there has been some loss of genetic variation in laboratory populations of the Hessian fly. Rapid genetic differentiation of insect populations in the laboratory can be accompanied by changes in behavior, physiology, body size, and activity patterns (Bush et al. 1976, Loukas et al. 1985). Assessing this possibility for the Hessian fly will entail electrophoretic examinations of both laboratory populations and the field populations from which they originated.

\section{Acknowledgment}

We thank John Foster for supplying bulk populations of biotypes B, C, and D (from Tippecanoe County, Ind.), E (from Daughtery Co., Ga.), and L (from Randolph Co., Ind.); and Jimmy Hatchett for supplying biotype GP (from Phillips Co., Kans.) and the Prosser, Wash. population. We thank Hang Pham and Bonnie Kot for their assistance and Guy Bush for the use of his laboratory. This research was conducted in cooperation with the Michigan State Agricultural Experiment Station, Michigan State University, E. Lansing, MI 48824, and the report is journal article No. 12212. Some of the sta- tistical computing was supported under NSF-BSR8315821.

\section{References Cited}

Brewer, G. J. 1970. An introduction to isozyme techniques. Academic, New York.

Bush, G. L., R. W. Neck \& G. B. Kitto. 1976. Screwworm eradication: inadvertent selection for noncompetitive ecotypes during mass rearing. Science 1193: 491-493.

Emigh, T. 1980. A comparison test for Hardy-Weinberg equilibrium. Biometrics 36: 627-642.

Gallun, R. L. 1977. Genetic basis of hessian fly epidemics. Ann. N.Y. Acad. Sci. 287: 223-229.

Harris, H. \& D. A. Hopkinson. 1976. Handbook of enzyme electrophoresis in human genetics. NorthHolland Publishing Company, Amsterdam.

Harrison, R. G., S. F. Wintermeyer \& T. M. Odell. 1983. Patterns of genetic variation within and among gypsy moth, Lymantria dispar (Lepidoptera: Lymantriidae), populations. Ann. Entomol. Soc. Am. 76: 652-656.

Hatchett, J. H. \& R. L. Gallun. 1968. Frequency of Hessian fly, Mayetiola destructor, races in field populations. Ann. Entomol. Soc. Am. 61: 1446-1449.

1970. Genetics of the ability of the Hessian fly, Mayetiola destructor, to survive on wheats having different genes for resistance. Ann. Entomol. Soc. Am. 63: 1400-1407.

Lewontin, R. C. 1965. Discussion of paper by Dr. Howard, pp. 481-484. In H. G. Baker \& G. L. Stebbins [ed.], The genetics of colonizing species. Academic, New York.

Loukas, M., A. P. Economopoulos, E. Zouros \& Y. Vergini. 1985. Genetic changes in artificially reared colonies of olive fruit fly (Diptera: Tephritidae). Ann. Entomol. Soc. Am. 78: 159-165.

Maruyama, T. \& P. A. Fuerst. 1985 . Population bottlenecks and nonequilibrium models in population genetics. III. Genic homozygosity in populations which experience periodic bottlenecks. Genetics 111: 691703.

Nei, M. 1972. Genetic distance between populations. Am. Nat. 106: 283-292.

Nevo, E. 1978. Genetic variation in natural populations: patterns and theory. Theor. Pop. Biol. 13: 121177.

Selander, R. K., M. H. Smith, S. Y. Yang, W. E. Johnson \& J. B. Gentry. 1971. Biochemical polymorphism 
January 1988 Wellso ET Al.: Hessian Fly Electrophoretic MonOMORPhisM

and systematics in the genus Peromyscus I. Variation in the old-field mouse (Peromyscus polionotus) Stud. Genet. 6: 49-90.

Sosa, O., Jr., \& R. L. Gallun. 1973. Purification of races $\mathrm{B}$ and $\mathrm{C}$ of the Hessian fly by genetic manipulation. Ann. Entomol. Soc. Am. 66: 1065-1070.

Spiess, E. B. 1977. Genes in populations. Wiley, New York.

Received for publication 4 June 1987; accepted 31 July 1987. 